\title{
OTROS CARIBES: \\ POSICIONES CONTESTATARIAS DESDE \\ LA COSTA ATLÁNTICA DE NICARAGUA
}

\author{
POR \\ María Roof \\ Howard University
}

\section{Dos Nicaraguas}

Las aguas de dos mares bañan las costas de Nicaragua, como de las otras repúblicas centroamericanas menos El Salvador. Y hasta hace poco esa dualidad se reflejaba en la percepción de "dos Nicaraguas" separadas en términos geográficos, económicos y étnicos: la del centro y de la Costa Pacífica y la "otra" de la Costa Atlántica o del Caribe, que formaba parte del territorio nacional, pero no del imaginario nacionalista. Poblado por indígenas miskito, rama y mayangna, por afrodescendientes garífunas y foráneos kriols anglófonos, ese $50 \%$ de la superficie nacional, con el $15 \%$ de la población, quedó excluido de la formulación etnocéntrica de la identidad nacional nicaragüense, que se definió como netamente hispana e indígena, es decir, mestiza. Entonces, con el Caribe, Nicaragua no tendría nada en común, ni historia, ya que no hubo grandes plantaciones dependientes de la importación de esclavos africanos, como en el resto del Caribe, ni cultura, ya que las prácticas sociales y celebraciones religiosas se derivaban del calendario español católico y no del folkclor indígena o de la cultura inglesa.

Ciertas búsquedas identitarias, sin embargo, han extendido la identidad caribeña a las zonas colindantes de la América Central y del Sur, y hasta de partes de la costa sureña de los Estados Unidos, como constata el escritor costarricense Quince Duncan, quien define el Gran Caribe como inclusive del Caribe insular y continental, de "la costa atlántica mexicana, toda la costa caribeña de la América Central, todo Belice, el istmo de Panamá, San Andrés, la costa atlántica del norte de Colombia y la costa atlántica del norte de Venezuela" (1-2). El "aspecto más característico es la impresionante diversidad cultural del Gran Caribe, con sus formas específicas de relación con el capitalismo internacional que data del siglo XVIII y la presencia étnica africana como el elemento constante" (2). Además, esta zona presenta una unidad porque "posee rasgos culturales que la distinguen, por ejemplo, de las zonas del interior del Continente y de la costa pacífica de cada uno de los países" (3). 
Para algunos teóricos, las islas y las litorales de la "cuenca" del Caribe constituyen una unidad geográfica y, más importante, vivencial en su historia de "azúcar y esclavitud" (en la expresión de C.L.R. James), su constante comunicación a través de cinco siglos de existencia colonial y neocolonial y el hilo esencial homogéneo de la "West Indianness" anglófona en sus culturas y expresiones literarias (Smart 109). Aunque Nicaragua no experimentara la economía de las grandes plantaciones de azúcar del resto del Caribe, se vio involucrada en la "máquina plantacional" en el sentido en que Antonio Benítez-Rojo interpreta las sociedades esclavistas y todos los sistemas relacionados que apoyaron a la máquina y constituían parte de ella (The Repeating Island).

\section{EUROINDOETNOCENTRISMO}

La colonia española había configurado "dos extensas regiones socio culturales y económicas distintas y distantes”: el Atlántico de los pueblos indígenas y el Pacífico, donde residiría la autoridad del Estado colonial, que con la independencia propuso el proyecto de Estado nacional de un poder mestizo, con pretensiones de homogeneidad lingüística con el español, además de homogeneidad religiosa (católica) y cultural (Torres-Rivas xiv). La construcción de la identidad regional y nacional por las élites del siglo XIX promueve la conceptualización de procesos de mestizaje europeo e indígena que produjeron un grupo bastante homogéneo unido por la lengua y cultura españolas (Gordon 121). En el siglo XX, la familia dictadora de los Somoza impulsó el mito de la Nicaragua mestiza, étnicamente homogénea desde el siglo XIX, con celebración de la herencia indígena por intelectuales de renombre como Pablo Antonio Cuadra (Gordon 121-25). Los kriols y los indígenas de la Costa Atlántica, no incorporados a la economía nacional, quedaron invisibilizados en estos procesos, a pesar de la supuesta "reincorporación" de la zona en 1894 por el presidente Zelaya.

Pablo Antonio Cuadra, ensayista sobre la identidad nicaragüense, omitió en El Güegüense la influencia genética y cultural africana. En el país donde la marimba nombre que desde ya suena al África- es un instrumento nacional..., no sólo omitió la influencia cultural del negro, sino que la negó. En su versión de la historia, "(n)uestra literatura con Rubén Darío nos salvó de esta falta de Atlántico - de esta falta de vivencia de la mediterraneidad caribe y de sus aportes europeos y africanos -inventándonos con su genio un mar suficiente [...]" (26). Esto es paradójico ya que en el libro que inaugura la literatura nicaragüense sobre temas nicaragüenses, Poemas Nicaragüenses, Pablo Antonio incluyó al negro en su poema titulado exactamente El negro, y lo incorporó como parte de Nicaragua, aunque supongo, porque no lo dice, que el negro entra a Nicaragua y pasa a ser asimilado por la cultura mestiza (Castro Jo 29).

Tampoco quedó visibilizado el ciudadano indígena, dada la "romantización del indígena del pasado, es decir, del indio muerto, cosa que no ocurre con el pasado africano y caribeño" (Castro Jo 21).

$111 \frac{\text { Revista Iberoamericana, Vol. LXXXII, Núms. 255-256, Abril-Septiembre 2016, } 421-455}{\text { ISSN 0034-9631 (Impreso) }}$ 
En la economía de enclave regida por los Estados Unidos a partir de 1920, Bilwi se redesignó "Puerto Cabezas" para la exportación madera y bananos y proveyó trabajo para los costeños y cierta identificación con los norteamericanos, reforzada por el auge en la extracción de oro, plata y cobre entre los años 1940 y los 70, la que entró en descenso hacia 1971 y llegó a su fin en 1978 (Frühling, González y Buvollen 40).

\section{Presencia africana en NicAragua}

La presencia africana en Nicaragua es de vieja data: "Los primeros esclavos negros habían llegado a Nicaragua como criados domésticos de eclesiásticos y de funcionarios de la Corona", a partir de la llegada de los primeros conquistadores en 1524, y sus descendientes llegaron a ocupar en el siglo XIX puestos en el servicio militar y judicial (Romero Vargas 23). Aunque "la población esclava negra era prácticamente insignificante en la Nicaragua colonial” (24), sus descendientes alcanzaron gran número; en 1790 la distribución étnica de la población de la vieja ciudad de Granada mostraba el $69 \%$ identificado como negros (4\%) o mulatos y zambos (65\%) (24). Resumiendo sus investigaciones en los archivos coloniales parroquiales y generales en Nicaragua, Guatemala, Sevilla y Valladolid, el historiador Germán Romero Vargas concluye que:

Un viejo mito, de origen colonial español, nos había acostumbrado a la idea de que el mestizaje nicaragüense era el resultado de la mezcla del indio con el español. Verdad a medias. El mestizaje, fenómeno social que está a la base de la nacionalidad nicaragüense, se inicia en el país en el siglo XVI y tiene tres componentes fundamentales: indio, europeo y africano. El negro africano fue absorbido por la sociedad indo-hispana. En tanto que negro, prácticamente desaparece. En tanto que mulato, no solamente sobrevive, sino que llega a constituir un amplio sector de la población. No se individualiza como mulato sino que se funde en la sociedad mestiza, que se sobrepone a la anterior diversidad étnica $[\ldots](34)$

El historiador cultural Jorge Eduardo Arellano adjunta datos sobre la continua presencia de africanos en la zona del Pacífico:

El primer esclavo negro llegó a Nicaragua en 1523, con Gil González Dávila, quien lo había comprado por trescientos pesos en Panamá. [... Nuestra zona del Pacífico, desde entonces, estuvo poblada -a lo largo de la época colonial- por esclavos originarios de África. [...] Para el dominante estrato español, "la pieza esclava" era símbolo de preeminencia social y propiedad apta para realizar con ella operaciones de compraventa, alquiler, préstamo, obsequio, juego, herencia e hipoteca. Con su incremento en la segunda mitad del siglo XVII, tras la introducción de una apreciable cantidad durante la gobernación de Diego de Artieda y Cherinos, de 1573 a 1586, los esclavos negros ampliaron las capas medias mestizas formadas -en su mayoría- por zambos (mezcla

$111 \frac{\text { Revista Iberoamericana, Vol. LXXXII, Núms. 255-256, Abril-Septiembre 2016, 421-455 }}{\text { ISSN 0034-9631 (Impreso) }}$ 
de negros e indios), mulatos (mezcla de español y negro) y cuarterones (los que tenían un cuarto de sangre africana) y demás mezclas. Estas constituían en 1820 el 84 por ciento de la población.

Por tanto, hasta la Independencia hubo más habitantes de sangre negroide en el Pacífico del país que en el Mosqueto Kingdown (Reino Mosquito). En efecto, allí los cimarrones y esclavos negros, procedentes de Jamaica, eran para 1768 unos 4,500.

El Atlántico "desatendido" quedó ocupado por los británicos desde el siglo XVII, en parte con el propósito de aislar España de la explotación de la costa, y proclamaron una especie de protectorado, "El Reino de la Mosquitia" bajo un rey nativo (1687), que duró hasta 1860. Los ingleses llevaron esclavos africanos a las plantaciones de azúcar y añil y su número aumentó con naufragios de buques que llevaban esclavos y esclavos amotinados puestos en tierra, además de inmigrantes negros libres en las islas anglófonas del Caribe, los cuales se congregaron alrededor de Bluefields como creoles urbanos, anglófonos. Después del Tratado de Versailles en 1783, los británicos se retiran temporalmente de la zona y "la población creol-de ascendencia africana-ganó influencia y llegaron migrantes negros de las islas caribeñas, especialmente cuando se abolió la esclavitud en las colonias inglesas en 1833. [...] El nuevo centro de poder fue Bluefields, donde la población negra había reemplazado a los miskitu como aliados estratégicos de los ingleses" (Frühling et al. 21). Hasta principios del siglo XX, los creoles seguían identificándose con los pueblos anglófonos, y entre los costeños de alianza estrecha con los Estados Unidos, el general Augusto César Sandino representaba "otro caudillo español” (32), porque los miskitu "no se definían como nicaragüenses, eran otro pueblo, ahora en alianza con los norteamericanos" (34), igual que los creoles.

La Costa Atlántica sufrió el abandono por el gobierno nacional hasta la década de 1950, que vio una serie de estrategias y políticas de transformación socioeconómica concordantes con la etapa "modernizante o desarrollista del Estado somocista" (Urtecho 100), ampliamente estudiada por Carlos M. Vilas como aspecto del desarrollo desigual del capitalismo en Nicaragua entre 1950 y 1979. Sin embargo, como legado histórico del abandono por el Estado nacional, "las comunidades afrocaribeñas establecidas en la zona lograron un desarrollo educativo muy avanzado, con el apoyo de iglesias protestantes, mantuvieron sus instituciones sociales y culturales básicamente jamaicanas con gran celo, y desarrollaron relaciones muy provechosas con los pueblos indígenas" (Duncan 182). Al comenzar la década de los años 1970s, los costeños tenían el más alto grado de alfabetización y de salud del país y una élite graduada de colegios y universidades, con instituciones culturales toleradas y hasta fomentadas por la familia Somoza, "que veía en su poca integración con la población del Pacífico una ventaja” (182).

La Costa Atlántica participó de modo limitado en la lucha contra la dictadura somocista, lo cual refleja y aumenta la desconfianza histórica entre las dos Nicaraguas (Frühling et al. 9; 351). Según Vilas, en las regiones con una activación revolucionaria 
previa, la Revolución llega "como poder establecido, como gobierno, con una dotación numerosa de funcionarios de fuera de la región que generalmente no la conoce bien" (citado en Urtecho 101). La población local tiene poca familiaridad con el discurso y la práctica de la Revolución, sus objetivos y estilos.

Al poco tiempo del triunfo de la Revolución sandinista en 1979, el líder del Frente Sandinista de Liberación Nacional (FSLN), Daniel Ortega, se reunió con la organización indígena ALPROMISU: “Ortega declaró que ya no existían indígenas en Nicaragua porque la revolución representaba la terminación de cada tipo de discriminación étnica o racista. Los miskitos ya no eran indígenas sino nicaragüenses [...]" (Frühling et al. 42), entonces, no eran necesarias las organizaciones de indígenas, sino que había que seguir el modelo cubano de organizaciones de masas, como los sindicatos, asociaciones campesinas y comités de barrio. Ni los indígenas ni los afrodescendientes entraron en la

\begin{abstract}
imagen prevaleciente [antes y después de 1979 que] correspondía a la del indio mestizado que ha perdido su lengua originaria y sus costumbres como efecto del desarrollo del capitalismo. Es evidente que el FSLN heredó, por su composición social, la visión de la ideología tradicional (tanto conservadora como liberal) tiene de la Costa: territorio "primitivo", "atrasado", es decir, algo que hay que integrar al progreso, a la civilización. (Urtecho 100)
\end{abstract}

El etnocentrismo existente en muchos cuadros dirigentes del grupo étnico dominante en Nicaragua, los mestizos, llevó a los sandinistas a asumir una actitud paternalista y la fantasía de que con nuevas instituciones revolucionarias la región recorrería en poco tiempo el trayecto político e ideológico que a los obreros y campesinos del resto del país les tomó un par de décadas (Vilas cit. en Urtecho). "El racismo y el afán divisionista de Ortega" se aprecia en la exclusión de los negros de la organización MISURASATA (Misquitos, sumos, rama y sandinistas) (Duncan 186). "El trauma racista heredado de la colonia" era una "nefasta tara que corroe el alma nacional en tanto no deja a las personas ser en libertad" (Duncan 218; destacado en el original).

Para el gobierno sandinista, la Costa Atlántica representaba una zona atractiva para la agroexportación a escala nacional y grandes proyectos estatales de inversión en palma africana, un nuevo puerto profundo, empresas forestales, el procesamiento pesquero -proyectos no concretizados por la guerra contrarrevolucionaria (Frühling et al. 89). Continúa luego el etnocentrismo del mestizo del Pacífico inherente en la incomprensión de la Costa Atlántica por los sandinistas y sus bien documentados intentos equivocados, por ejemplo, el de forzar el desplazamiento de comunidades indígenas de zonas de peligro durante el conflicto contrarrevolucionario. ${ }^{1}$

Ver detalles en Frühling et al.

$111 \frac{\text { Revista Iberoamericana, Vol. LXXXII, Núms. 255-256, Abril-Septiembre 2016, } 421-455}{\text { ISSN 0034-9631 (Impreso) }}$ 
Paradójicamente, la revolución sandinista desencadenó el "primer encuentro real de las dos Nicaraguas", pero con el desenlace trágico de la que Costa Atlántica fuera un "teatro de brutal guerra" entre 1981 y 1987 (Frühling et al. 344). En la década de 1980 Estados Unidos abandonó el mantenimiento de la infraestructura de servicios en la Costa, energía eléctrica, caminos puertos, y la guerra cambió la faz de la Costa: arrasó con la tradicional agricultura y pesca de subsistencia; forzó la migración del campo peligroso a las ciudades; cortó la producción pesquera; paralizó la industria minera; y el Huracán Joan en octubre de 1988 destruyó el 70\% de las casas y las plantas procesadoras de la zona.

Los sandinistas consideraban a los campesinos miskito potenciales colaboradores con la resistencia y los trataron como tales. ALPROMISU se reorganizó como MISURASATA, la organización de miskitos, sumos (luego llamados "mayangnas") y ramas unidos con el sandinismo. Luego, MISURASATA rompió la alianza con los contras y propulsó la lucha de los indígenas a favor de la autodeterminación (Frühling et al. 61). En 1983, el gobierno sandinista cambió de actitud, emitió una amnistía general y entró en negociaciones con los grupos costeños con miras a alguna forma de autonomía para la región. En 1987, la Ley de Autonomía, la Ley 28, creó la autonomía étnico-territorial casi sin precedentes en la historia contemporánea de América Latina, una experiencia única y novedosa (Frühling et al. 3). "En la medida en que el Estado Nacional se fortalezca y en la Costa Atlántica se genere una nueva forma de convivencia humana las naciones multiétnicas de América Latina tendrán en Nicaragua una lección, una experiencia, un ejemplo" (Torres-Rivas xx).

Los afro-caribeños quedaron concentrados en la región del Atlántico Sur, siendo la cultura más fuerte la de los de creoles, generalmente de habla inglesa -descendientes de esclavos y de africanos rebeldes y libres- y los garífunas). Sin embargo, el cuadro comparativo de la población de la Costa muestra grandes cambios en la composición total y relativa:

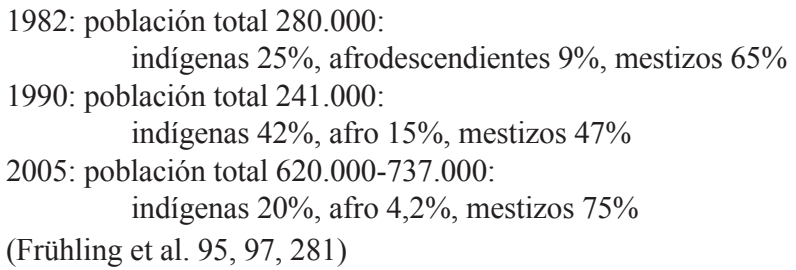

El régimen de la autonomía ha incrementado la presencia de los mestizos en la Costa y rebajado el nivel de extensión de los afrodescendientes. Éstos y los indígenas son las poblaciones más minoritarias, en composición nacional y en la de la Costa Atlántica, con menos multietnicidad en las regiones autónomas. La lucha por visibilizar

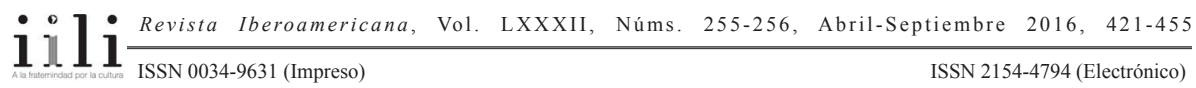


las regiones autónomas, con el tiempo, se ha convertido en la lucha por defender los derechos permanentes de las minorías étnicas (Frühling et al. 328).

Una encuesta en la Costa Atlántica de 1997 valoró superior la identidad indígena y afro a la identidad nacional; pero para 2004, la mayoría de los creoles y de los rama se consideraban tan nicaragüenses como miembros de su etnia. Se reportó además la tendencia en todo el país de afirmar la identidad regional, de aprobar el concepto de una nación multiétnica, con diferentes costumbres y lenguas, pero se consideraba la Costa Atlántica una zona de peligro, delincuencia, drogas y folklore, y el $71 \%$ de los nicaragüenses reconocieron que todavía hay racismo contra las poblaciones indígenas y negras (Frühling et al. 325-328).

\section{AutonOMÍA: ReSCATE Y RECUPERACIÓN CULTURAL Y LINGÜÍSTICA}

Se ha notado la "inclusión restringida en el Régimen de Autonomía" de los indígenas y los "étnicos” en los procesos políticos, además de tensiones entre los dos grupos en cuanto a coaliciones estratégicas. La Organización de los Pueblos de la Madre Tierra (YATAMA), por ejemplo, se negó a incluir los derechos de grupos no indígenas en su lucha porque implicaría alejarse de su principal objetivo (González 111). Las organizaciones políticas locales quedaron excluidas de los procesos políticos regionales, con el resultado de la inclusión limitada de los indígenas y afrodescendientes en los derechos de ciudadanía multicultural (116).

Se organiza la Fundación para la Autonomía y Desarrollo de la Costa Atlántica de Nicaragua (FADCANIC) "para juntar recursos y voluntades que consoliden e impulsen la experiencia de la autonomía”, que describe así la culminación de la búsqueda de autonomía y los resultados actuales:

En septiembre de 1987, la Asamblea Nacional de Nicaragua aprobó la Ley 28: "Estatuto de Autonomía de las Comunidades de la Costa Atlántica de Nicaragua”. Esta ley reivindica las demandas históricas de sus 6 pueblos indígenas y comunidades étnicas de mayor inclusión y espacios de participación efectiva, en la toma de decisiones de orden político, social y económico; oportunidades decisorias para el manejo y aprovechamiento de los recursos naturales y ambientales; el respeto y visibilización de las tradiciones histórico-culturales propias.

Las Regiones Autónomas de Nicaragua (Región Autónoma del Atlántico Norte-RAAN, y la Región Autónoma del Atlántico Sur-RAAS) fueron creadas en 1987, eligiendo sus primeros gobiernos regionales en 1990 .

A pesar del Estatuto de Autonomía, el territorio de la Costa Atlántica ha estado sometido a un elevado aislamiento respecto al resto del país, debido a un rezago histórico que hoy se manifiesta en la falta de inversiones sociales y productivas, en la ausencia de infraestructura de transporte, desarticulación de la estructura productiva regional,

$111 \frac{\text { Revista Iberoamericana, Vol. LXXXII, Núms. 255-256, Abril-Septiembre 2016, 421-455 }}{\text { ISSN 0034-9631 (Impreso) }}$ 
inseguridad ciudadana, limitada cobertura de servicios básicos y un marco institucional todavía débil.

Su población original la constituyen pueblos indígenas y comunidades étnicas con características multilingües (Miskitus, Creoles, Mestizos, Mayangnas, Ramas y Garífunas), situadas en territorios con un fuerte sentido de pertenencia de sus tierras comunales que habitan en los litorales y zonas interiores de alta vulnerabilidad ecológica y ambiental. [...]

Entre un $73.6 \%$ y el $75.0 \%$ de la población de la Costa Caribe Nicaragüense vive en situación de pobreza y extrema pobreza. Los habitantes que han logrado conseguir un empleo reciben ingresos muy bajos que apenas les permiten cubrir un $50.0 \%$ de la canasta básica, y de esos ingresos, el $80.0 \%$ se destina para la compra de productos alimenticios. (FADCANIC, "Regiones Autónomas de Nicaragua")

Uno de los indudables resultados exitosos de la Autonomía fue la creación a partir de 1992 de centros universitarios dedicados a fortalecer el proceso de autonomía mediante la educación intercultural y bilingüe y el rescate de la identidad, cultura e historia de la Costa. La Universidad de las Regiones Autónomas de la Costa Caribe Nicaragüense (URACCAN), con cuatro recintos actuales: Bilwi/Puerto Cabezas, Las Minas (Siuna), en la Región Autónoma Atlántico Norte, y Nueva Guinea y Bluefields en la Región Autónoma Atlántico Sur, "surge como una reivindicación histórica, a la demanda de la población costeña de un sistema de educación superior que responda a sus particularidades socio económicas y político culturales" (URACCAN, "Reseña histórica de la Universidad"). La universidad privada fundada por la Iglesia Morava, la Bluefields Indian and Caribbean University (BICU), ha asumido la publicación de una revista de suma importancia para los estudios culturales, lingüísticos y literarios, Revista Wani (fundada 1984), publicada por el Centro de Información y Documentación de la Costa Atlántica (CIDCA). Además de la inclusión de poetas costeños, ha publicado cuentos creoles e indígenas y abordado la cuestión étnica, el inglés creole nicaragüense, la lengua garífuna, la literatura creole, y componentes culturales como el Palo de Mayo.

\section{Tema negro en Nicaragua: Rubén Darío}

En Nicaragua, Carlos Castro Jo analiza "la conciencia de color que tiene el mestizo", como expresión y reflejo de una ideología racial del grupo social dominante que "revela aspectos importantes sobre el escritor, así como también sobre la sociedad en que vive" (21-22). Entre los cantores de conciencia mestiza "deslumbrados por el Caribe o por la influencia cultural negra", incluye a Rubén Darío y Manolo Cuadra que dejaron "afirmaciones equivocadas o racistas" (22). Ambos escritores tocaron el tema de las personas africanas y, dado su renombre en la historia literaria nicaragüense, habrían contribuido al trasfondo ideológico estereotípico contra el cual los poetas posteriores 
escriben. Al mismo tiempo, reflejan el trasfondo internacional en el cual el tema es tratado. En su artículo, "Segregacionismo dariano" (2002), Erick Aguirre analiza el contenido racista del ensayo "La raza de Cham" (1907), reflexión para "caracterizar la naturaleza de los seres de raza negra que pueblan el planeta, en especial los de Norteamérica", en el contexto de "las noticias que en aquel tiempo llegaban a París, acerca de frecuentes linchamientos y la constante agitación de los negros contra los blancos en Haití". Darío observa que en Haití, "En el negro, danzante, tristón, jovial, pintoresco, carnavalesco, surge, con el fuego de la cólera y el movimiento de la revuelta, el antepasado antropopíteco, el caníbal de África, la fiera obscura de las selvas calientes..." (211), lo cual califica Aguirre de "cierta noción ambigua, de alguna manera racista o segregacionista, respecto a la raza negra", cuando Darío cita a un "atinado" escritor argentino que:

planteaba que en Estados Unidos los negros, "la negrada", constituía todo un problema social debido a su igualdad legal, o civil, respecto al blanco.

Los negros de los Estados Unidos son los más osados, los más audaces que puedan existir sobre la superficie de la tierra [...] El romanticismo lo hermoseó todo, hasta los negros. En realidad, apenas el heroísmo es el que salva al pobre hijo de Cam del ridículo que trae como fatal herencia desde el materno vientre. Necesitan para brillar el resplandor de la pólvora o la grandeza del suplicio. La humanidad no ha podido aún ver el genio negro. El talento mismo es en ellos escaso, fuera de ciertas especiales disciplinas, a las cuales se adaptan su agilidad y su don de imitación. (Darío 215, cit. en Aguirre)

Darío también cita la “sabia opinión” de Rémy de Gourmont, crítico literario francés, que justifica la separación de las razas y proclama la excelencia de un "patriotismo de la raza", que al igual que el "patriotismo del suelo", debe "defender su casa contra los ladrones". Concluye que el rechazo a la raza negra por parte de las otras razas (sajones, latinos, celtas) es "natural" y "bello", y que el linchamiento de negros, ante esas circunstancias, está plenamente justificado (cit. en Aguirre).

Cierta ambigüedad surge al preguntarse, apunta Aguirre, "si aquel corresponsal de La Nación que escribía entusiasmado sobre la inferioridad de los negros, habría sido el mismo que, alguna vez, también se preguntara si en sus venas corría alguna gota de sangre africana. Y lo más probable es que la respuesta a esa pregunta fuese indudablemente afirmativa, a despecho de sus 'manos de marqués' y de la vida y el tiempo que le tocó vivir", respuesta confirmada por estudios posteriores. El médico Pablo Amaya retoma el análisis de "La raza de Cham" de Darío citando el ensayo de Aguirre y la "sabia memoria" de un doctor brasileño Roxo referida por Darío en estos términos: “"después de haber estudiado en todos sus pormenores las perturbaciones mentales en los negros, resulta que es un hecho probado que la raza negra es inferior: en la evolución natural es retardataria, y mientras el cerebro de los negros no entre en un periodo de actividad creciente, será una utopía la nivelación de las razas"” (cit. en Aguirre).

$111 \frac{\text { Revista Iberoamericana, Vol. LXXXII, Núms. 255-256, Abril-Septiembre 2016, } 421-455}{\text { ISSN 0034-9631 (Impreso) }}$ 
Castro Jo señala otros escritos de Darío no examinados por Aguirre que confirman una actitud despreciativa hacia el negro, "El Salomón Negro" y "El linchamiento de Puck", y le asombra "la falta de espíritu crítico de Rubén al tratar este tema en este cuento, y la forma en que naturaliza y acepta la ideología racista". Darío "muestra claramente su creencia en la superioridad del blanco" en poemas como "La negra Dominga" -que ofrece "una caricatura, un personaje que es un remedo de persona, una máquina sexual que se muere por conquistar a los hombres blancos" (24) - y "El porvenir" en que Darío "encuentra algo que celebrar en cada continente, menos en el África, que es 'la tierra donde moran / los hombres de piel negra, / hijos de Cam, que por su desgracia ignoran / y a quienes claro día nunca alegra, / porque es raza de esclavo y precita, / raza sin libertad, raza maldita"” (citado en Castro Jo 24).

Estas opiniones racistas, o segregacionistas, de un Darío "influenciado por la ideología racista de Europa y los Estados Unidos [que] creía que los negros eran inferiores" (Castro Jo 24), formaban parte del caudal intelectual que circulaba en el Pacífico mestizo de la época y formaría parte del trasfondo ideológico que nutriría a los escritores contemporáneos y futuros.

\section{PoESÍA NEGRISTA O DE TEMA NEGRO}

En diversas literaturas del Caribe aparecen expresiones poéticas, anteriores a los movimientos de la Negritud, o de reclamo de la herencia africana y que manejan el tema negro, aunque los poetas no sean de ascendencia africana. Recordemos, por ejemplo, los precursores que "sin ser biológica o culturalmente antillanos, fueron influidos en su creatividad por la presencia antillana” (Smart 13, traducción mía), tales como Luis Palés Matos en Puerto Rico, Emilio Ballagas en Cuba y Manuel del Cabral en la República Dominicana.

El decano de las letras nicaragüenses, Pablo Antonio Cuadra, abarca el tema negro en el poema ya mencionado, "El Negro", y en "Jalalela del esclavo negro", pero con su perspectiva mestiza burlona. Jorge Eduardo Arellano nota su uso de vocabulario africano: "Creer que la vida es moronga y el porvenir chorizo" (aplicada a la personas displicentes, que no valoran los esfuerzos de los demás). Vocablo, por otra parte, poematizado por Pablo Antonio Cuadra en su "Jalalela del esclavo negro": "Barato el esclavo, /y no come pan!... Cara de moronga /negrito rezonga: Porque no mi dan -porque no mi dan”.

Castro Jo identifica en Manolo Cuadra, poeta vanguardista nicaragüense, una tendencia racista en su desdén por la población negra y su creencia en la superioridad del hombre blanco, habiendo vivido por un tiempo en la Costa Atlántica (24-25). No referido por Castro Jo es el "Único poema del mar" de Cuadra, que habla de una "Miss Christine Braughtigam" que vive en Coconut Island, "hija de una isleña negra / y de un viejo pirata de Holanda", y que caracteriza al cuerpo del personaje poético como

$111 \frac{\text { Revista Iberoamericana, Vol. LXXXII, Núms. 255-256, Abril-Septiembre 2016, } 421-455}{\text { ISSN 0034-9631 (Impreso) }}$ 
"alegre y esbelto, como el de un junco ahumado" y hace eco del estereotipo de la mujer negra sexuada: "envuelta en su maillot de fuego / [...] se sumerge en las aguas / iy es entonces una brasa que se apaga!" Los pájaros de la isla piden ayuda cuando "una ola traicionera" se lleva "a la perla de canela" y "Christine busca la caricia del mar afuera. / ¡Quién colmara urgencias de su sangre negra!” El escenario de la Costa sobresale en Coconut Island, "donde aburro mi destierro frente al Mar Atlántico. [...] y cantan los negros sus canciones esclavas, / indiferentes, [...]".

Estos poemas, entonces, sí introducen el tema negro de la Costa Atlántica, presentan caricaturas y estereotipos raciales, donde los afrodescendientes forman parte de la naturaleza. "Más común que un racismo abierto en algunos textos de los poetas deslumbrados se puede notar una insensibilidad étnica" en las obras de Manolo Cuadra y de Ernesto Cardenal, cuya "poesía 'costeña' se refiere al paisaje y a los indígenas de la zona". Fernando Silva, en su poema "Al ritmo de Bluefields", "refleja su conciencia de color, y entiende la diferencia cultural entre él, un mestizo, y el negro" (Castro Jo 25) y define al negro como "otro", reflejando insensibilidad étnica, "especialmente porque fue escrito en los 70 cuando la militancia étnica negra sólo existía entre un grupo pequeño de intelectuales y jóvenes radicales. [...] Las referencias al físico de los negros y los símiles e imágenes ('el negro como de hule'), más [la referencia a] el maleficio que no podía faltar, hacen una lista que raya el borde de los estereotipos raciales que tienen los mestizos sobre el negro" (Castro Jo 26).

En algunos poetas Castro Jo nota que el color de la piel no es el principal modo de identificar a una persona, ya que "no se usa como marcador de algo significado" si es que se menciona, por ejemplo en Manuel Martínez, Alí Aláh (seudónimo de Santiago Navas) y José Santos Cermeño, como también en el novelista Lizandro Chávez Alfaro (27). Santos Cermeño "trata de adaptar los ritmos caribeños a su poesía, a la manera de Nicolás Guillén. Él trató de escribir una poesía negra nicaragüense, si con esto queremos decir una poesía que usa los ritmos de la canciones del Palo de Mayo" -en su "Blanquinegra canción de las neninas", "Palo de Mayo en Bluefields" y "Jardín en Beholden"- en que "se refiere a una serie de tópicos como el color de la piel, la cultura, el sexo, con un respeto por el pueblo que está describiendo [... y muestra] una actitud totalmente opuesta a la de escritores como Manolo Cuadra" (28). Julio Valle-Castillo lo considera un escritor importante en la continuación del tema negro en la poesía nicaragüense:

Cermeño significa la entera y consciente asunción de la temática y expresión afrocaribeña moderna [...] ("La negra Dominga" de Rubén Darío, Nicolás Guillén y Emilio Ballagas en Cuba y las otras Antillas), y en Nicaragua se había anunciado con Luis Alberto Cabrales ("Canto a los sombríos ancestros"), Manolo Cuadra ("Único poema del mar"), Pablo Antonio Cuadra ("Jalalela del esclavo bueno" y "Negro") y Alberto Ordóñez Argüello ("Oración de negra”). [...] 
A [Cermeño] se debe un descubrimiento o deslumbre poético de la otra realidad, de la otra historia y del otro costado del país, más sistemático. Un poeta puente, unificador entre la cultura del Pacífico y la del Atlántico: la negritud propia, de Bluefields, Oldbank, Beholden, Rama, Corn Island, con sus comidas, como run down y sus danzas de may pole, las Chinas de la China, las onomatopeyas, el bilingüismo criollo, el ritmo y musicalidad, estos dos últimos rasgos que le eran tan suyos y hasta el elemento de denuncia social que la realidad le impone. Rasgos todos que caracterizan a la poesía de la negritud de América. A partir de Cermeño, el paisaje fluvial y marinero de la Costa Atlántica serán una constante en la poesía de Nicaragua. ("Los cien años de Santos Cermeño y de Bluefields")

Al incluirlo en su antología, Bluefields en la sangre, los editores citan a Santos Cermeño como creador de: "la nueva poesía del Atlántico, mejor dicho, cierta poesía del Atlántico: la de Bluefields, que es una poesía inscrita estilísticamente en el movimiento negrista de las Antillas, que tuvo su mayor auge en los años treinta y su mejor expresión en la obra de Nicolás Guillén, afirmación tal que la podemos constatar en sus temas, en el ritmo, en las onomatopeyas y en las jitanjáforas de sus poemas" (Alemán y Brooks 13). Como muestra de su poesía que entronca con la antillana, de "Palos de Mayo en Bluefields", con una rítmica evocación de las canciones de la celebración de mayo:

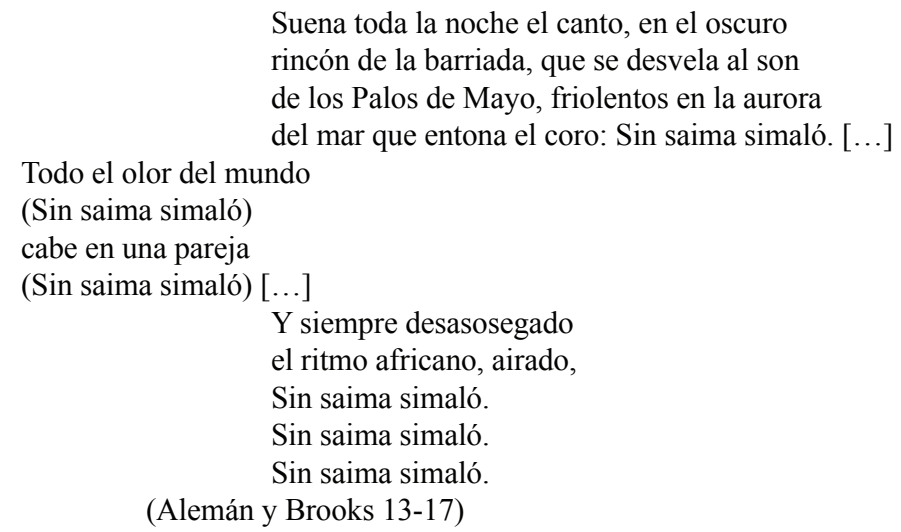

Santos Cermeño repite esta incorporación poética de los ritmos de la celebración de mayo en su "May Pole in Bluefields", que incluye otra canción del inglés criollo de la Costa Atlántica:

$[\ldots]$

(Mayaya lost the ky

Mayayaón).

$111 \frac{\text { Revista Iberoamericana, Vol. LXXXII, Núms. 255-256, Abril-Septiembre 2016, } 421-455}{\text { ISSN 0034-9631 (Impreso) }}$ 


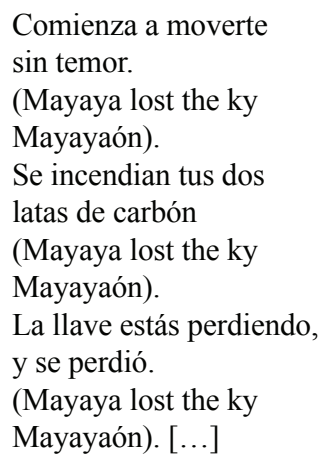

(Alemán y Brooks 20-21)

Se ha debatido en la historiografía el origen tanto de las expresiones criollas como de la celebración del Palo de Mayo. Algunos las relacionan con la diosa mítica "Maya", de herencia africana invocada en busca de fertilidad: "Poca información existe sobre el origen de esta deidad, pero sería lógico verla como una forma de la Oricha traída del África, conocida como Yemayá y venerada en varias partes del Caribe, Centroamérica, Cuba y Brasil" (Edison 24). Sin embargo, el Palo de Mayo se reconoce como una tradición inglesa "de rendir homenaje a los espíritus de los árboles [que] fue traída por los británicos, y por intercambios transculturales se [convirtió] en una celebración que refleja la cosmovisión de la Costa Atlántica" (26).

Uno de los historiadores más prominentes de la CostaAtlántica, Donovan Brautigam Beer, argumentó en los años setenta la procedencia europea del Palo de Mayo, como vocero de un movimiento culturalista que buscara establecer la diferencia cultural criolla costeña que había de incluirse en la identidad nacional como una cultura de igual valor que otras y así contrarrestar el etnocentrismo del Pacfíco, al generar el discurso creole contrahegemónico referente a la identidad que prevaleció en los años 70 (Gordon 173). El Palo de Mayo sería una manifestación de la confluencia de culturas que creó una celebración nueva en la Costa Atlántica, donde prevalecen las costumbres británicas más que las africanas (Gordon 170). Esta tradición se equipara a otras prácticas culturales sincréticas, como el candomblé en Brasil, el vudú en Haití, la santería en Cuba, "socialreligious practices that emphasize the powerful presence of African heritage in resisting apparatuses of discrimination" (Falola y Roberts 122). Excelente ejemplo, entonces, del uso de las tradiciones antillanas en la resistencia a la hegemonía del etnocentrismo mestizo. 


\section{CELEBRACiÓN DE LA HERENCIA AFRICANA Y ANTILLANA}

Como Julio Valle-Castillo, Carlos Castro Jo reconoce como cantores de temas africanos a dos poetas del Pacífico que "celebran el color de su piel oscura y los ancestros africanos, Luis Alberto Cabrales y Alejandro Bravo" (29). De Cabrales es el temprano "Canto a los sombríos ancestros" (1932) que se dirige a los antepasados africanos y muestra su orgullo de la herencia africana y su continuación en el Nuevo Mundo a través de la voz poética:

Tambor olvidado de la tribu

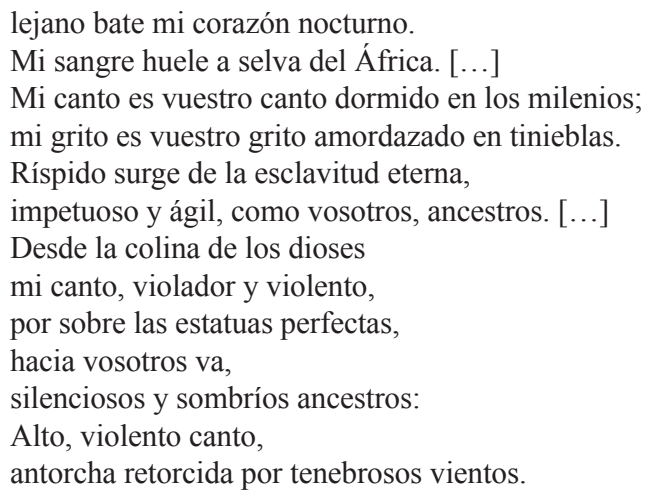

Esta canción de protesta y reivindicación coincide con las poesías del Caribe francófono del movimiento Negritud de Aimé Césaire (Martinica) y Léon Damas (Guyana Francesa) en su reclamo de la herencia africana.

Si el resto de Nicaragua identificaba raíces españolas e indígenas, omitiendo el ADN y la cultura africana contribuyentes al ser nacional, la costa caribeña a veces reclamaba su procedencia negra, aunque, parecido a lo ocurrido en otras partes, no sin divisiones internas y distingos entre antiguos residentes y advenedizos (confiérase el debate en Panamá entre los afro coloniales y los afro antillanos llegados con la construcción del Canal en los siglos XIX y XX, y en Honduras, entre los garífunas coloniales y los angloparlantes).

La década de 1970 vio "el despertar de la conciencia étnica en América Latina", el cual implica nuevas formas de organización política y artística (Duncan 183). Entre las primeras voces consideradas auténticas expresiones del Caribe Afrocaribeño surgen las de David McField (El Rama, 1936) y de Carlos Rigby (Laguna de Perlas, 1945), escritores casi epónimos con "Nicaribe", cuyas obras han sido seleccionadas para la inclusión en todas las antologías de la región costeña. Para el crítico y antólogo Julio Valle-Castillo, la voz poética caribeña corresponde al "canto de la negritud, como toda la

$111 \frac{\text { Revista Iberoamericana, Vol. LXXXII, Núms. 255-256, Abril-Septiembre 2016, } 421-455}{\text { ISSN 0034-9631 (Impreso) }}$ 
diversidad étnica cultural que esto implica" en el país "en cuyo mestizaje o hibridación... reside su multiculturalidad e identidad", compuesta de indígenas del pacífico, del centro y del caribe, el español y criollo, el negro, el asiático (Valle-Castillo, El siglo 344). Destaca en McField y Rigby, ambos poetas negros y oriundos de la Costa Atlántica, la celebración de mayo como el mes de la fecundidad de la tierra, la danza y la música, con estructura rítmica y musical.

Sin embargo, ninguno de estos escritores comenzó planteando la identidad necesariamente negra de la Costa Caribe. De hecho, en sus primeros libros, McField "integra el imaginario costeño, con elementos ingleses y antillanos" (Valle-Castillo, El siglo 346), pero sin mencionar elementos raciales o étnicos. La gran mayoría de sus poesías no aluden a la identidad costeña o a etnias, sino que se vuelcan hacia temas políticos, sociales y amorosos. En su tercer libro, Poemas para el año del elefante (1970), menciona el tema racial sólo en un poema sobre un beisbolista, "Cuando el equipo de León", y ahí resulta ser un canto a la multietnicidad del personaje de nombre y apellido antillanos, Duncan Campbell, orgullo de todo el país, orgullo de todos los negros, y beisbolista "de ojos medio achinados". Tampoco Rigby crea el imaginario costeño en términos raciales.

McField sostiene dos vertientes en sus poesías: (1) la unión de "los de abajo", el pueblo, los obreros, ciudadanos de toda raza y etnia, para la lucha política contra la dictadura somocista; y (2) el panafricanismo, la identificación de la diáspora con el continente, planteamiento desde su temprano poema "Black is Black" hasta su más reciente "Tangañika". A diferencia de la mayoría de los costeños que se desentendieron de la lucha contra la dictadura, McField une las dos vertientes en su primer poemario, "multirracial e insurgente, Dios es negro-'Dios es negro, como Nkrumah / como Lumumba', el que vino a marcar en 1967 un hito para la literatura de la Costa Caribe por su negritud rítmica y realismo social" (Agüero). Posteriormente elogiado por recalcar la multiculturalidad de Nicaragua, McField "hizo de la poesía un arma contundente contra la dictadura y dignificó la incorporación de su raza a la lucha por la dignidad. Su fe en la presencia de un Dios negro, al lado de los marginados, llenó de optimismo los ideales de libertad" (Espinoza Moncada). En 2008, siendo oficial del gobierno sandinista (y ahora, su embajador en Jamaica), sigue proponiendo la unión de los pobres en un crisol de razas, donde "están los negros, los indios, los sumos... Ahí estamos todos" (cit. en Espinoza Moncada).

Este es el mensaje de múltiples poemas suyos de diversos libros publicados antes y después del triunfo de la Revolución. En la nota "Al lector" de En la calle de enmedio (1968), declara la mayor identidad de los hombres por lo que tienen en común, hasta tal punto que "es difícil definir quién es quién" (McField 15). El hastío vital o banal del hombre común conduce al miedo que impone inactividad ante la guerra que no comienza. Sin embargo, aunque encuentra la ciudad muerta y sin hombres, donde "no hay quien

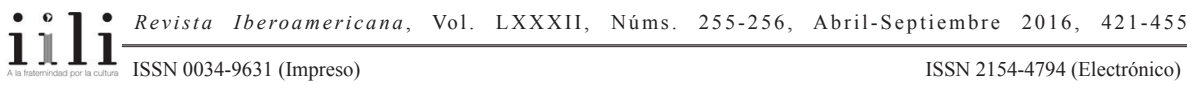


levante la voz", Poemas para el año del elefante (1970) y Poemas populares (1972) anuncian que la voz bajará de la montaña para convocar a todas las voces ("UNÍOS") en la unión para dar el golpe. Equipara al pueblo sacrificado al suplicio del crucificado y nombra al Frente Sandinista y a la revolución armada como única solución.

$\mathrm{Y}$ efectivamente, algunos de sus poemas, especialmente canciones y villancicos de Las veinticuatro (poemas y canciones) (1975) fueron incorporados a los cantos revolucionarios por los Mejía Godoy y otros, y "se volvieron canciones populares escuchadas por más de un millón de nicas en las décadas pasadas, como 'Pancasán', 'Nació el niño negro', 'Tiene que cambiar'” (Agüero). Aunque un crítico opina en 2000 que "padecen la contaminación frentista-seudo-revolucionaria", reconoce que "después de 21 y 25 años, una buena parte de esos poemas está fresca. Ejercen la negrización, el repudio del icono católico, capitalista, burgués" (Yllescas Salinas). Y prima el concepto de los héroes internacionales unidos en la política sino en la raza, de su poema "Poetas del exilio": Antonio Machado, Pablo Neruda, García Lorca, Ciro Alegría, Sandino (¿McField mismo?).

"Black is Black" (Poemas populares, 1972) introduce el panafricanismo, primero en la identificación de los miembros de la diáspora:

en cualquier latitud.

Ser negro da lo mismo,

Black is Black.

Si no que lo digan,

las magníficas actuaciones de Sid Poitier,

los formidables músculos de Jim Brown,

Caupolicán moderno,

o Lotario, fiel como el golpe que asesta a los enemigos

de Mandrake.

[...]

Negro en los muelles de New York

en Old Bank

en los algodonales de Atlanta

en Vietnam, Laos y Camboya [...] (37)

Obviamente, en la alusión al héroe Caupolicán de los indígenas mapuche de Chile, McField une su lucha con el alto concepto del negro en la iconografía popular, y en la moderna con Mandrake, y la lucha general de los oprimidos con la raza negra de la diáspora. En este sentido extiende la "cosmovisión transcultural que integra elementos africanos, indígenas y europeos" (Edison 22) hacia otros pueblos oprimidos. Ángela Davis, profesora y activista africanoamericana es otra figura diaspórica señalada por McField como héroe (Poemas populares).

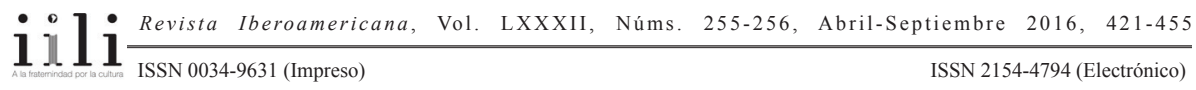


“Oyendo unos tambores en Tangañica”, escrito mientras fungía McField como embajador sandinista en varios países africanos en los 1980, refuerza la unión de la diáspora con el continente de origen:

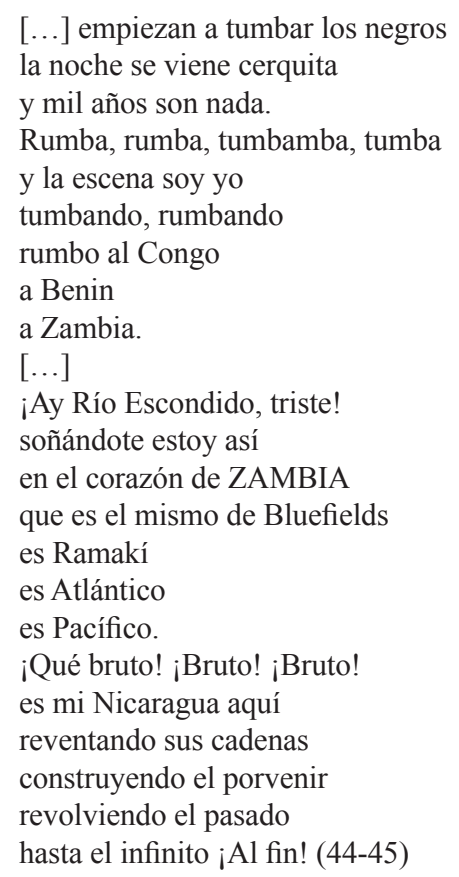

El otro reconocido cantor de la Costa Atlántica, Carlos Rigby, "uno de los mejores poetas del Caribe" (Alemán y Brooks 73), aborda temas del Atlántico, del Centro y del Pacífico, y con coloquialismo costeño, "traduce y cruza el inglés criollo con el español popular, generando neologismos, bilingüismos y juegos de palabras inusitados que hacen que el cuerpo del poema se mueva con gran sensualidad" (Valle-Castillo, El siglo 347). Al igual que la denuncia social y política en las poesías de McField, en las de Rigby, "las letras de las canciones del palo de mayo y sus estribillos van más allá de la fiesta para presentar una realidad de pobreza y marginalidad.... Desde su verbalismo lúdico y bilingüe, Rigby teoriza sobre su identidad nica-caribe" (347), para la cual crea la metonimia muy citada, "Nicaribe soy"-"Yo soy de Nicaribia-/ nicaribe soy..." (Alemán y Brooks 78). Rigby teje los ritmos y los motivos naturales, sociales y culturales de la costa -Palo de Mayo, "sim-sáima-sima-ló", patti ron-down, Tropical Reggae, "máyaya lasiqui máyaya-ooo", Corn Island- en la creación literaria no como elementos exóticos ni decorativos sino para la denuncia o el elogio políticos que abarcan 
todo el país (aunque, inexplicablemente, Smart descarta a Rigby por una supuesta falta de suficiente "West Indianness"):

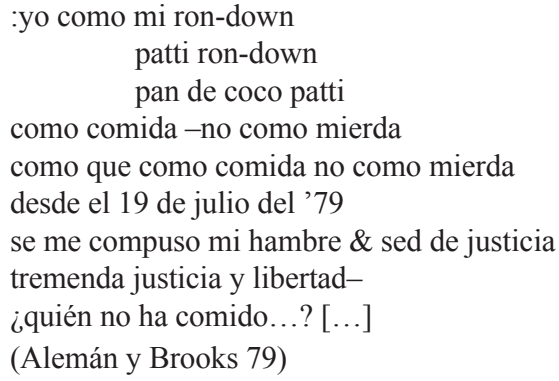

Varios críticos han comentado los metros orales tradicionales procedentes de Africa en Rigby, y la destrucción del metro tradicional poético español mediante la musicalidad y fórmulas ideofónicas, "versificación enriquecida por los ritmos tradicionales orales africanos, con versos que pueden extenderse de uno a dos versos ideofónicos con varias sílabas variadas" (Kubayanda citado en Edison 26).

Propia de la Costa Atlántica como del resto del país es la lucha por la libertad y la justicia, en Rigby, apoyada por el Frente Sandinista. Igual que McField, Rigby dice: “:yo creo en la Revolución [...] ...yo creo en los Pueblos \& su Revolución” ("Los pirománticos" 524), nombrando a héroes de la lucha de otras tierras centroamericanasOtto René Castillo, Roque Dalton y desarrollando una sostenida analogía relacionada con productos farmacéuticos muy comunes:

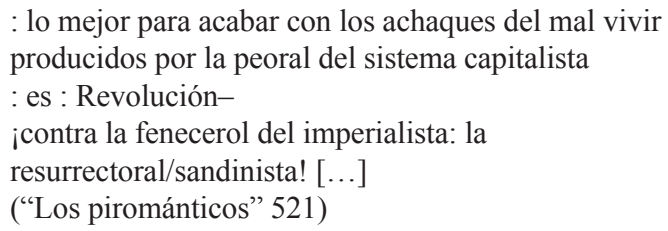

A diferencia de la presentación simplista de McField en la brevedad de sus poesías de la división entre "los de abajo" y los ricos, Rigby sigue la pauta del Frente Sandinista en su interpretación clasista y la negación del factor raza/color en la solución a la situación sociopolítica, en su "Todo clasial / nada racial", a la vez que repasa las antiguas connotaciones ligadas a las razas:

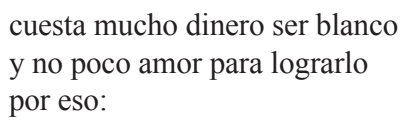

$111 \frac{\text { Revista Iberoamericana, Vol. LXXXII, Núms. 255-256, Abril-Septiembre 2016, } 421-455}{\text { ISSN 0034-9631 (Impreso) }}$ 
ni blanquinegro

ni blanco y/o negro

para mí son todos los colores o nada

:yo quiero sólo los colores que hay en mi clase

y no

la clase de colores de que pintan mi humana raza

todo clasial -nada racial

$[\ldots]$

cuántas vidas cuesta el dinero/yla cantidad de muertos

/para mantenerlo con vida

: el precio de las libertades mínimas/y la más

/cara de todas

$[\ldots]$

...dinero

aprendido en escuelas capitalistas

: ¡todo el dinero o nada!: en nosotros se ensañan

/y enseñan sus dinerólogos

: todo es dinero o nada $[\ldots]$

("Todo clasial / nada racial" 525-27)

Estos últimos dos poemas, además del contenido político, reflejan al Rigby considerado:

a very distinguished poet who introduced a new rhythm to poetry, a new way of writing poetry, new word play of poetry as drum sound, trumpet sound, contrabasso sound, musical sound, the word as music, verse conserving music within itself. That is, going back to the roots, recovering music as an instrument of poetry. [...] Carlos Rigby, one of the strongest poetic personalities of the country, not just the Coast, but the country. (Alemán Ocampo)

En el análisis de la conciencia de raza y color en la literatura nicaragüense, Carlos Castro Jo concluye que: "Rigby, 'nuestro gran poeta inédito', [...] siempre ha peleado porque se incluya la cultura caribeña como parte de la cultura nacional, y esa cultura caribeña de la que él habla es negra y también indígena. Al mismo tiempo, él ha escrito sobre la necesidad de trascender la división racial para hacer un proyecto popular basado en la lucha de clases y la lucha contra el racismo simultáneamente" (30-31). McField y Rigby imponen y suponen la inclusión de la Costa Caribe en el imaginario nacional y utilizan los elementos culturales derivados de la raza y de la cultura caribeña para fundamentar la reconstrucción de Nicaragua sobre bases más justas y equitativas. 


\section{NueVOS DERROTEROS}

Gracias a la obra de estos poetas y diversos estudios etnográficos, como los de Aguirre y Amaya, se ha revisado la imagen del Darío "afrancesado, exótico y alienado" para reclamar "su aporte a la lucha por la independencia cultural de nuestros pueblos de América Latina, negra e indígena, a través de su vida y de su magnífica poesía de resistencia frente al yanqui invasor", siendo una característica particular de la poesía nicaragüense, y de su pueblo, "un valor de libertad y resistencia" (Avellán vi). Con la autonomía de la Costa Atlántica y la declaración del país como pluriétnico, esa resistencia y libertad toma diversas formas también pluriétnicas, que podemos analizar como continuaciones de vertientes anteriores, pero condicionadas por las realidades contemporáneas. Contribuye al conocimiento de las nuevas poesías la publicación de extensas antologías de poesía del Caribe: Antología poética de la Costa Caribe de Nicaragua, editada por Víctor Obando Sancho, Ronald Brooks Saldaña y Eddy Alemán Porras, publicada por la editorial de la nueva universidad, URACCAN, en 1998, con 33 poetas y 70 poemas, y Bluefields en la sangre: Poesía del Caribe Sur Nicaragüense, editado por Eddy Alemán Porras y Franklin Brooks Vargas en 2011, con 38 autores y 169 poemas, ambas incluyentes en términos de género, diversidad étnica, geográfica y temática. Como explica Víctor Obando Sancho en la introducción a la segunda antología: "Los pueblos de la Costa Caribe de Nicaragua, a raíz de la publicación de la Ley 28 o Estatuto de Autonomía experimentan una serie de cambios en sus reivindicaciones y aspiraciones en lo cultural, económico, político y de género. Para ellos apelan a sus raíces culturales para no perder su identidad. [...] Es ineludible el tema del cambio o las aspiraciones cuando hacemos poesía" (5). Otras antologías, como las de Julio ValleCastillo, Neovanguardia, y Héctor Avellán, Nicaragua: El más alto canto, refuerzan el concepto de la Costa Atlántica como territorio nacional al incluir a sus poetas, identificándolos con su procedencia geográfica, pero sin ponerlos en categorías apartes.

Entre las principales direcciones actuales de la poesía de la CostaAtlántica, podemos formular las siguientes agrupaciones:

\section{CANTO Y DEFENSA DE LA AUTONOMÍA}

La socióloga, antropóloga y poeta costeña Yolanda Rossman Tejada, en su tesis, "La Autonomía multicultural desde la poesía de escritoras costeñas", señala que:

la flagrante ausencia de las voces indígenas y afro descendientes exige acciones que redimensionen el análisis de la producción literaria como forma cultural articulada a relaciones de producción concretas en las Regiones Autónomas. Los hallazgos confirman que las mujeres están escribiendo en sus lenguas maternas, aunque aún invisibilizadas. La difusión y divulgación de su producción literaria no ha sido sistematizada. La lectura

$111 \frac{\text { Revista Iberoamericana, Vol. LXXXII, Núms. 255-256, Abril-Septiembre 2016, } 421-455}{\text { ISSN 0034-9631 (Impreso) }}$ 
de los poemas nos presentan una diversidad de temáticas pero todas confluyen en un eje común: el proceso transformador que se vive en las Regiones Autónomas. (cit. en Watson, "Las reacciones" 55)

Y este eje común, el proceso de la Autonomía, en la mayoría de los casos, se conceptualiza como un devenir positivo y prometedor. Erna Narciso (Bluefields, 1942), de etnia creole, mantiene la costumbre antillana de escribir poemas en inglés, pero también alaba en español la autonomía en términos que reflejan la continuidad de los planteamientos de McField y Rigby, en su "Autonomía":

$[\ldots]$

Permitan que nuestra Autonomía

sea un símbolo reconocido por el mundo entero,

pero no como un emblema de corrupción y vergüenza. [...]

Recordemos que Autonomía es darnos las manos

los mestizos, indígenas, ramas, garífunas y,

por supuesto, los creoles.

La Autonomía es abrazar al débil y al fuerte

y a los que por siempre han sido oprimidos. [...]

y unámonos voluntariamente

para defender nuestra tierra y nuestra Autonomía.

(Alemán y Brooks 63)

Otros poetas refuerzan la lectura de la autonomía como unión de las diversas etnias de la Costa Atlántica, como la creole Lovette Martínez (Bluefields, 1952), quien escribe en inglés y en español y propone esta interpretación del significado:

"It Is Autonomy"
Autonomy is Rama's power
autonomy is Sumus power
autonomy is Garifunas power
and why not? Miskitos, mestizos and creoles power.

Autonomy is unity in diversity

autonomy is equality

autonomy is strength.

Autonomy is speak and study in our mother tong

sing and dance our traditional songs [...]

participate in making decisions

keeping our environment and our natural resources clean. [...]

(Alemán y Brooks 108)

$111 \frac{\text { Revista Iberoamericana, Vol. LXXXII, Núms. 255-256, Abril-Septiembre 2016, } 421-455}{\text { ISSN 0034-9631 (Impreso) }}$ 
Este sueño optimista sugiere cierto paraíso terrenal echado a perder pero, según Marvin Ramírez (Bluefields, 1949), pescador, productor agrícola y poeta creole, el desastre ecológico se superará en el futuro:

Hoy solo está en mi mente

lo que queda de aquel Paraíso Viviente. [...]

¿Quién les hizo daño?

machetes, hachas y motosierras. [...]

Los bosques volverán a soñar

y los ríos volverán a cantar,

porque siempre habrá un sembrador,

un poeta y un soñador.

(Alemán y Brooks, “Campos azules” 97-98)

La interpretación idealista, pero no folklorista, señala una vertiente importante de la producción poética caribeña que no descarta la promesa de unión y utopía que algunos vieron en la autonomía.

Como yo señalara en el estudio "Más allá de la revolución: Poesía por mujeres nicaragüenses" (2007), en el período posrevolucionario se nota una distinción remarcable entre la poesía de las dos costas: el Caribe Nicaragüense contrasta con la mayoría de la poesía actual femenina nicaragüense. La Región Atlántica con nueva autonomía, nueva universidad, nueva editorial y nuevas poetas afirma el optimismo arraigado en su historia distinta. Annette Fenton (Bluefields, 1973) escribe en un inglés criollo y propone cierta moralidad tradicional basada en el trabajo y la superación por el esfuerzo individual: "That di failure to accomplish goals is only one of plenty kina ways Fa gain strenght and / character, until e wake up the wise master ah e soul E goping get some weh" ("Di first thing"). A diferencia del desengaño y sensación de fracaso de sus contemporáneas radicadas en la costa del Pacífico, Ileana Lacayo (1974) canta a la autonomía regional en términos que recuerdan los sueños de las Generaciones del 60 y del 70 (Roof 104):

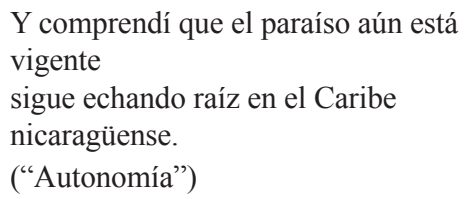

Brenda Green (Bluefields, 1954), de etnia creole, expresa el optimismo como parte de la esencia costeña, geográfica y racial en su "Soy costeña":

Esta alegría caribeña que siente tu negrísima costeña,

$111 \frac{\text { Revista Iberoamericana, Vol. LXXXII, Núms. 255-256, Abril-Septiembre 2016, } 421-455}{\text { ISSN 0034-9631 (Impreso) }}$ 
compartirla contigo quiero, quiero borrar de tu rostro esa tristura y contagiarte con mi energía vivaracha ... Ven y endulcemos juntos cada momento disponible de los dos.

(Alemán y Brooks 129)

Algunas de las poetas jóvenes del Pacífico postulan el escapismo del "ridículo mundo" a través de las drogas, el licor y el sexo, como Natalia Hernández Somarriba (1982) en "Domingo naranja":

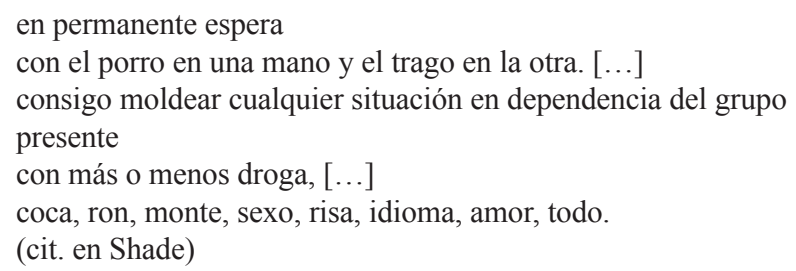

Nada parecido entre los poetas del Atlántico. A diferencia de aquella generación de la "noluntad" de la Costa Pacífica, que reniega de los ideales de la generación de sus padres que derrocó a la dictadura, Suyén Bolaños Chow (Bluefields, 1974), de etnia mestiza, expresa cierta preocupación por el mundo que ella heredó y que legará a sus hijos, "un mundo sin mejoras", de "contaminación inevitable" de "enemistad con la naturaleza", una "patria fatigada" y "castigada". Sin embargo, no duda en asegurarle al hijo que también le entrega "este mundo multicolor/ [...] con algunas hojas de árboles que se esconden / en inmaculados rincones de nuestra región" ("Súplicas de perdón y versos para un mundo mejor"). Entonces, unido al optimismo y la seguridad de que "la esperanza de cambiar las cosas / sobrevive todavía", propone la permanencia de la región costeña como reserva ecológica intocada, ideal. Algunos identifican la integridad de la Autonomía en la preservación de sus recursos naturales, como el pastor moravo creole Allan Budier (Bluefields, 1962) en su breve poema "Encomio"; la destrucción ambiental y de recursos económicos constituyen una amenaza para la Autonomía; cuando los ríos estén secos, los árboles derrumbados, el oro terminado y los camarones y langostas todos exportados, “¡PAZ A TUS RESTOS, AUTONOMÍA!”.

\section{ORGULLO NEGRO}

Si los costeños creoles hasta la década de 1960 negaban o subestimaban sus raíces africanas, prefiriendo la construcción de una identidad histórica trasnacional y predominantemente británica (Gordon, 18, 97, 126), las poesías de McField y Rigby 
y el despertar de la conciencia étnica en América Latina a partir de 1970 obraron un cambio en el imaginario étnico, con "Dios es negro", "Black is Black", la Negritud y los ritmos africanos incorporados a la poesía. La "alegría caribeña" de la "negrísima costeña" Brenda Green continúa la vertiente de la poesía de la Costa Atlántica que reclama la herencia afro. En su "Identity", la poeta declara:

It's a fact that I'll always face, 'cause I surely love my race, very proud that I am black and no one can turn that back. (Alemán y Brooks 132)

Isabel Estrada Colindres (La Fé, Cuenca de Laguna de Perlas, 1953), bilingüe en inglés y español, reclama la etnia garífuna en términos fenotípicos y tradicionales como una permanencia en la continuación de la cultura en su "Yesterday":

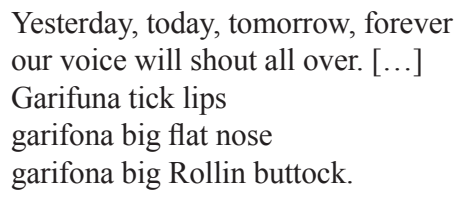

When I horde the sound of my father drum drum, drum, drum the sound of my grandfather drum drum, drum, drum my feet keep moving on mother ground for the healing of our ancestors wallagallo. [...] (Alemán y Brooks 118-119)

Indistintamente de su etnia, los costeños parecen haber abrazado como propias las tradiciones creoles, para combinarlas con un rechazo de la raíz identitaria española, como en el caso de Orlando Cuadra Tablada (1960, Bluefields), quien se autodefine como de etnia mestiza pero coincide con Rubén Darío en maldecirle a Colón la llegada a su parte del mundo ("iPluguiera Dios las aguas antes intactas / no reflejaran nunca las blancas velas"), la que considera "el inicio de una historia funesta / llena de esclavitud sanguinaria, de engaños", y por eso en un 12 de octubre, "no hay NADA que celebrar!" (Alemán y Brooks, “¿Celebrando qué?” 169-170). Sin embargo, entre las "raíces metafísicas" encuentra nítida la raíz africana:

$111 \frac{\text { Revista Iberoamericana, Vol. LXXXII, Núms. 255-256, Abril-Septiembre 2016, } 421-455}{\text { ISSN 0034-9631 (Impreso) }}$ 


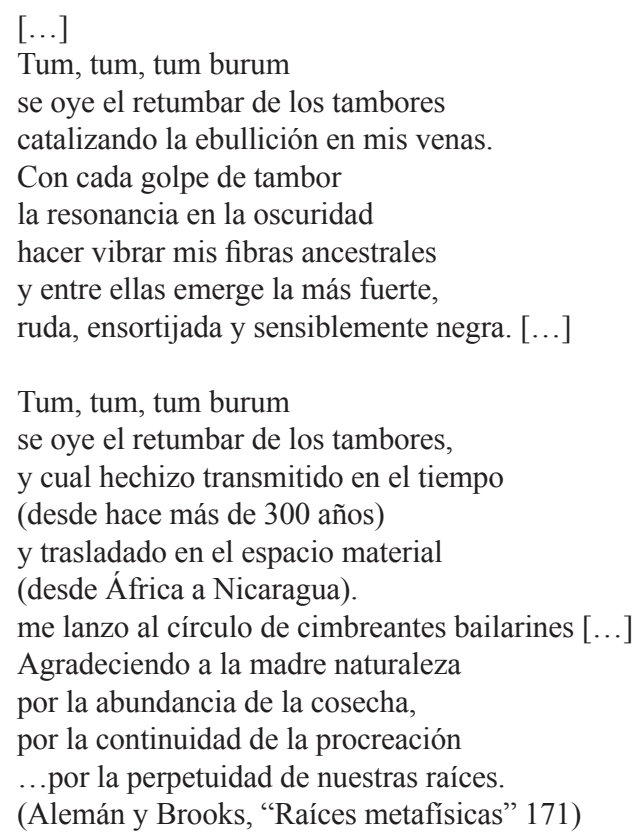

Los ejemplos abundan del nuevo, o renovado, orgullo negro u orgullo de las raíces africanas. El poeta que se define como "mestigro" por el abuelo negro y la abuela mestiza, Franklin Brooks Vargas (Bluefields, 1960), escribe su "Canción al negro/negra costeño/a", que si peca de idealista en hablar del "paraíso" de la bahía "prodigiosa" y percibir que "las figuras de los botes y los negros pescando / parecen bellas manchas en el cuadro único del paisaje / que ningún pintor podrá plasmar en su tela", declama su contento con su "propia sonrisa de negro" (Alemán y Brooks 178-180).

Andira Watson (Bilwi/Puerto Cabezas, 1977) replica al "Dios es negro" de McField en su poema, "Diosa negra", pero utilizando las estereotípicas asociaciones de la mujer negra con la sexualidad:

Dios en nuestras bocas es una blasfemia pero su nombre emerge gramíneo [...] "¡Misericordia! -dices-, ¡misericordia!”. Dios nos ha fundido por esta noche desde los genes. ¡Dios debe ser una Diosa de mi color! (47) 
Watson se une a la expresión del orgullo negro expresado por la costarricense Shirley Campbell Barr, a quien dedica su "Rotundamente negra", en el momento en que asume su propia identidad africana:

Soy como vos Shirley
Rotundamente negra
Vivo en Managua y
desayuno
rice and beans
green banana
bread fruit
ginger tea
black tea
La gente me ve blanca
pero yo me siento negra
Negra como mi padre
como mis primas

Negra como mi hermano y mi abuelo

Soy como vos Shirley un árbol robado de África [...]

(Nicaragua 224)

Andira Watson continúa su expresión de las raíces africanas en su "Reclamo de Negritud”- “África/-Aquí estuvo mi estirpe- / En esta tierra ajena de sí/ que alguna vez fue nuestra casa-", pero en la remembranza de un viaje a África como representante de un programa de cooperación sur-sur de HIVOS, "Zimbabwe en la memoria", comenta cierto rechazo de ella por parte de un africano:

Preservo la risa de un joven africano que no comprendió por qué mi poema "Rotundamente negra" afirma un ser que no existe. Porque no soy negra de piel y es ridículo que me autoproclame negra, según él. Le daba risa. Y no le culpo. La África que reivindicamos es la de memoria ancestral y el color-diluído en míde la autoestima restaurada por tantos siglos de opresión racial.... De nada sirve contarles que provengo de la Costa Caribe de Nicaragua y que mi lado paterno es afrodescendiente, que supuestamente vinimos desde Jamaica y antes de eso, de Nigeria.

Por mucho tiempo sentimos vergüenza de tener el estigma de la africanidad en nuestras venas. Se trata de una experiencia histórica de silenciamiento, de invisibilidad que hoy ponemos de manifiesto como afro descendientes. Aunque África, tal vez ya no nos recuerde. 
Ese orgullo de la ascendencia africana podría verse, entonces, como un fenómeno netamente anclado en la diáspora y de reciente expresión entre los nicaragüenses.

\section{RECLAMO DE LA PLURIETNICIDAD}

Sin exagerar demasiado, tal vez podamos ver un símbolo de la identidad costeña en el mismo Palo de Mayo cantado en tantos poemas, considerando la observación de Thomas Edison de que "el festival del mes de mayo es el eje a través del cual las distintas clases económicas, niveles sociales y pasiones eróticas se juntan por un breve momento cósmico" (Edison 29, con mención de ideas similares en Octavio Paz). La unión en la diversidad se notó en la construcción identitaria por razones políticas o estratégicas en las propuestas de McField y Rigby, y luego en la simbología de la autonomía, el proceso de "darnos las manos / los mestizos, indígenas, ramas, garífunas y, / por supuesto, los creoles" en las palabras de Erna Narciso (63), la autonomía como el poder unido de los ramas, sumos, garífunas, miskitos, mestizos y creoles, según Marvin Ramírez. Pero halla su expresión también en la identidad personal de varios poetas, como el ya mencionado "mestigro" Franklin Brooks Vargas, y también en la definición de la región costeña. Teoriza la poeta Andira Watson que ante: "el limbo identitario en que nos encontramos a la hora de asumir una identidad étnica que no se limita a un solo grupo étnico, nos toca, entonces, volver la vista hacia nuestras raíces valorando el aporte que cada cultura nos ha dado, sabiendo que somos, como ha dicho la poeta guatemalteca Maya Cú, producto de la historia, entendiendo que nos habitan por igual, un indígena, un africano y un colono" ("Las reacciones" 57).

Julio Monterrey (Bluefields, 1962), mestizo, también reclama la herencia indígena y africana de su región, "tierra de ardientes soles", donde los ancestros "nunca doblaron la frente / nunca ante cascos hirientes", y llegaron:

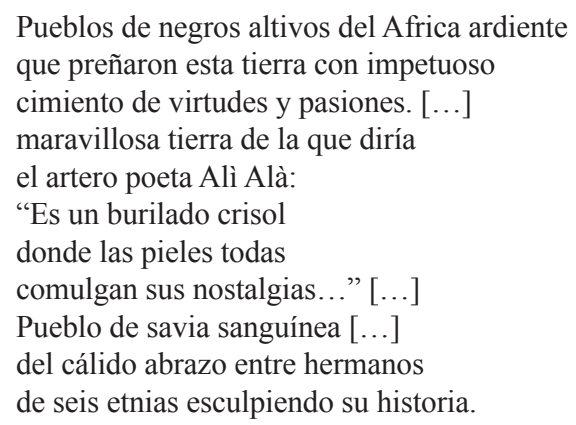

(Alemán y Brooks, "Un burilado crisol” 198-199) 
La lograda poeta Yolanda Rossman Tejada, reclama entre sus raíces a la abuela materna rama que se juntó enamorada a un mestizo, y a:

\author{
Mi abuela paterna \\ Ardiente mujer KRIOL, \\ Con un toque de NAGA \\ Mágica, poderosa, \\ Hizo sucumbir \\ Con su inquietante aroma a flores, \\ Al ojiazul emigrante alemán, \\ Venido del viejo continente.
}

Soy crisol,

Soy amalgama,

Sangre, lengua, piel

¡SOY MUJER DEL CARIBE!

("Raíces")

Karl Tinkam (Laguna de Perlas, 1967), escritor bilingüe en inglés y español, de etnia creole y garífuna, canta a la herencia negra de la diáspora en su "I Have A Dream"-el sueño garveyano del retorno a África (pero a un continente idealizado y estereotipado, con niños jugando, leones rugiendo y palmeras ondeando “sus hojas en señal de paz"). Pero no aísla la herencia negra de las otras y sigue la pauta sugerida por Andira Watson de valorar el aporte de cada cultura en su "Soy quien soy":

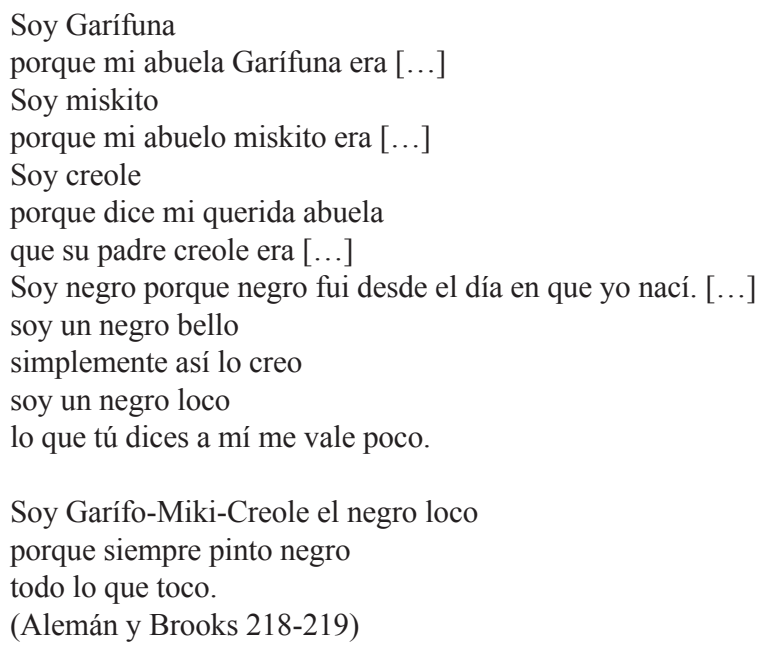

$111 \frac{\text { Revista Iberoamericana, Vol. LXXXII, Núms. 255-256, Abril-Septiembre 2016, } 421-455}{\text { ISSN 0034-9631 (Impreso) }}$ 


\section{SíNTESIS DE LA CUESTIÓN ÉTNICA}

Una última tendencia en la reclamación de la identidad costeña parece apartarse de la cuestión de las etnias para enfatizar un acervo de valores, la cultura de la "patria chica", o el terruño del lugar geográfico de nacimiento, como exponeAlta Hooker, rectora de URACCAN: "Ser costeña es antes de ser nicaragüense. Significa vivir y aprender a comportarse en este entorno, construir y lograr ser parte de esta identidad" (citado en Sirias Duarte 56). A la eterna pregunta, ¿Quién soy?, responde Inés Hernández García (Bluefields, 1977), mestiza, en "Yo soy":

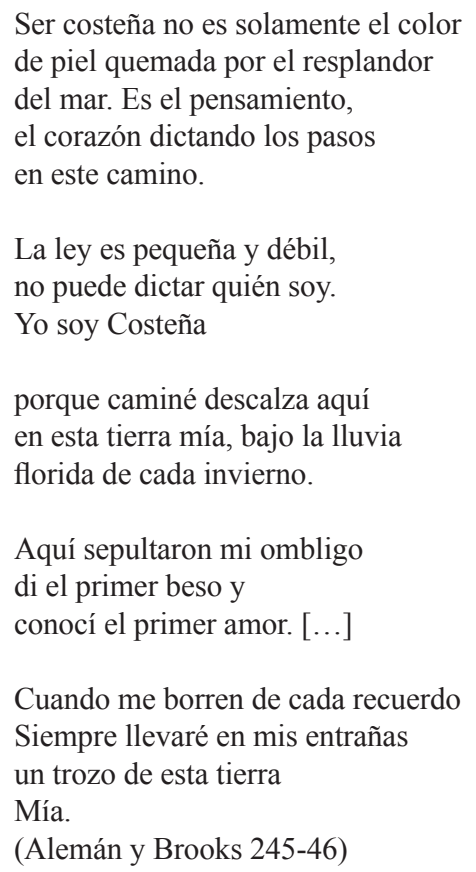

No tan curiosamente, entonces, la identidad costeña ha evolucionado como expresión de los cambios demográficos y comenzado a distanciarse de consideraciones de etnia y de la historia que produjo la estancia en una determinada zona geográfica de poblaciones oriundas de distintas partes del mundo. Ser costeño puede significar haber nacido allí, o en otro lado, ser de cualquier etnia, y haber adoptado las costumbres y los valores que son también productos de la historia. Los rasgos típicos de las tradiciones culturales caribeñas, el Palo de Mayo, por ejemplo, ya se consideran parte del acervo nacional nicaragüense, con su performance en la Costa Pacífica ahora igual que en la Atlántica, 
introducido por los mismos poetas, McField y Rigby, que intentaron establecer un diálogo entre las dos Nicaraguas e incorporar a la "otra" dentro de un nuevo concepto de una sola nación pluri- o multicultural. Siguieron tendencias poco racializadas, como la "clasial" de Rigby, para llegar a la posibilidad de la superación de la identificación entre fenotipo, raza, etnia y cultura, la que ya se sugiere en poemas como el de Hernández García y los análisis de ciertos costeños, como apunta William Grigsby:

Una dirigente feminista, Matilde Lindo Crisanto, abogada y socióloga, graduada en Cuba, considera que la influencia de la raza dominante en cada territorio terminará por absorber culturalmente a todos los demás grupos étnicos. Según Matilde, orgullosa representante de la raza negra nacida en Bilwi, hay personas que pueden ser negras con todas las características negroides, o pueden ser blancas con todas las características físicas de un chele, o pueden ser chinas con todas las características de un asiático, pero dicen que son mískitas. Afirman ser mískitas y además lo asumen con propiedad. La "mescolanza de culturas" señalada por Grigsby refleja el proyecto autonómico poético de alabar la visión utópica de la unión de las etnias en un solo proyecto. Noel Campbell Hooker, ingeniero químico formado en las universidades de León, Polonia y Estados Unidos, y gerente de producción de un laboratorio farmacéutico de Managua, concuerda con el criterio de Matilde sobre la influencia determinante de las culturas autóctonas sobre los grupos de mestizos, y en ello cifra sus esperanzas de que la Autonomía perdurará más allá de las etnias. Una persona de Masaya -dice [Campbell Hooker]- llegó a Bluefields. No come las comidas de la Costa ni le interesa la música costeña, pero usted observa y verá cómo ya sus hijos y sus nietos se hicieron costeños. [...] La segunda y tercera generación de masayas tienen la misma necesidad de ser escuchados y de participar, y por eso son autonomistas, casi con igual fuerza que un caribeño autóctono. Llega un momento en que, por alguna razón, la segunda y la tercera generación son absorbidas por la forma de ser de los bluefileños.

La forma en que los habitantes de Bluefields ven el mundo -continúa Campbell- es resultado de la dinámica participación de piratas holandeses y franceses, de los domados moravo-germanos del centro de la antigua Checoslovaquia $-\mathrm{y}$ digo domados porque su férrea disciplina germana tuvo que acomodarse al trópico-, de los implantados descendientes de africanos no esclavizados, y de los taciturnos indios ramas. Por esa mezcla, que está ahí, es por lo que creo que todos los que vivan en el Caribe se seguirán sintiendo diferentes a los del resto del país y por lo tanto, seguirán sintiendo como una necesidad propia la Autonomía. Y es por esa mezcla que yo digo que, aunque étnicamente seamos minoría, nuestra forma de ver el mundo seguirá siendo moldeada por las formas originales que nos trajeron estos pueblos.

El desplazamiento de grandes números de mestizos de las zonas norte y central del país hacia las regiones autónomas ha llevado a varios estudiosos a preguntar si las etnias están en las vías de extinción en la Costa Atlántica (ver Grigsby para más datos y referencias). El crecimiento exponencial en la población mestiza de la costa,

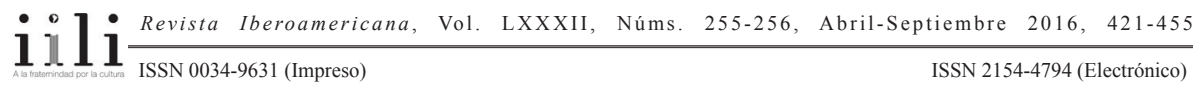


después del fin de la guerra contrarrevolucionaria en 1990, refleja las oleadas sucesivas de campesinos pobres desplazados que, empezando en la década de 1950, avanzaron la frontera agrícola mediante la ocupación y la deforestación de tierras ancestrales indígenas, expulsados de sus terrenos y de fuentes de ingresos por la mecanización de la producción agrícola para la exportación (el algodón, por ejemplo). A partir de los sesenta, la reforma agraria y la expansión de la industria ganadera aumentaron la atracción de las regiones autónomas para los campesinos pobres, sin tierra, sin trabajo, sin acceso a beneficios del Estado y sin posibilidades de estabilidad económica en las zonas rurales (ver detalladas explicaciones en Alfaro Mcfield). Además, ejerce su poder la nueva colonización de otra índole: "de dizque empresarios extranjeros y nacionales que ocupan deliberadamente territorios vírgenes como auténticos depredadores de sus valiosos recursos naturales. Su voracidad, que no parece tener límites, arrastra consigo a centenares de familias paupérrimas de las zonas rurales de prácticamente todo el país" (Grigsby).

Las nuevas tendencias poéticas costeñas reflejan esta nueva demografía y el imaginario caribeño que reclama una comunidad unida por valores, experiencias vitales, incluso del lugar geográfico, costumbres, historias asumidas y compartidas, y esperanzas del cumplimiento de las aspiraciones de la CostaAtlántica al bienestar cultural y económico. Algunas de las poesías más recientes reflejan la larga trayectoria de las voces contestatarias al proyecto nacional y proponen la posibilidad de la coexistencia y/o tolerancia necesaria para un nuevo orden que, utópico o no, cifra y pone en práctica las mejores esperanzas de toda la comunidad.

\section{BiBLIOGRAFÍA}

Agüero,Arnulfo." Dios es negro"”. Entrevista con David McField.La Prensa Suplemento, 12 abril 2008. $<$ http://archivo.laprensa.com.ni/archivo/2008/abril/12/suplementos/ prensaliteraria/entrevista/entrevista-20080411-1.shtml>. 21 dic. 2013.

Aguirre, Erick. "Segregacionismo dariano". El Nuevo Diario. 20 abril 2002. <http:// archivo.elnuevodiario.com.ni/2002/abril/20-abril-2002/opinion/opinion6.html>. 1 junio 2013.

Alemán Ocampo, Carlos. "The Culture of Power: Indigenous and Afro-Caribbean Literature in Nicaragua”. URACCANUpdate. $<$ http://www.yorku.ca/cerlac/uraccan/ URACCAN_update_November2000.htm>. 4 abril 2008.

Alemán Porras, Eddy y Franklin Brooks Vargas, eds. Bluefields en la sangre: Poesía del Caribe Sur Nicaragüense. Managua: 400 Elefantes, 2011.

Alfaro Mcfield, Elmer. "Autonomy of the Atlantic Coast of Nicaragua: A Review of Power and Resource Sharing among Minority Groups”. Tesis de Maestría California State University, 2007. <http://bosawasrioindiomaiz.wordpress.com/2011/09/15/ 
autonomy-of-the-atlantic-coast-of-nicaragua-a-review-of-power-and-resourcesharing-among-minority-groups $>.07$ dic. 2013.

Amaya, Pablo. "Rubén Darío: puntualizando controversias". El Nuevo Diario. 25 julio 2012. <http://www.elnuevodiario.com.ni/opinion/258743>. 01 junio 2013.

Arellano, Jorge Eduardo. "Afronegrismos en nuestro español". El Nuevo Diario. 4 abril 2008. <http://www.elnuevodiario.com.ni/opinión/12291>. 30 mayo 2013.

Avellán, Héctor. "Poesía urgente". Introducción. Nicaragua: El más alto canto. v-vii. Benítez-Rojo, Antonio. The Repeating Island: The Caribbean and the Postmodern Perspective. $2^{\text {a }}$ ed. James E. Maraniss, trad. Durham: Duke UP, 1996.

Bolaños Chow, Suyén. "Súplicas de perdón y versos para un mundo mejor". Bluefields en la sangre: Poesía del Caribe Sur Nicaragüense. Eddy Alemán Porras y Franklin Brooks Vargas, eds. Managua: 400 Elefantes, 2011. 238-40.

Budier, Allan. "Encomio". Bluefields en la sangre: Poesía del Caribe Sur Nicaragüense. Eddy Alemán Porras y Franklin Brooks Vargas, eds. Managua: 400 Elefantes, 2011. 202.

Cabrales, Luis Alberto. "Canto a los sombríos ancestros". Movimiento de Vanguardia de Nicaragua: Análisis y antología. Pedro Xavier Solís. 2002. <http://sajurin. enriquebolanos.org/vega/docs/CCBA\%20-\%20SERIE\%20LITERARIA\%20-\%20 11\%20-\%2008.pdf>. 01 mayo 2013.

Castro Jo, Carlos. "Raza, conciencia de color y militancia negra en la literatura nicaragüense". Revista Wani 33 (2003): 21-32.

Congress, Rick. The Afro-Nicaraguans: The Revolution and Autonomy. Atlanta: Atlanta Committee on Latin America, 1987.

Cuadra, Manolo. "Único poema del mar". <http://www.dariana.com/Panorama/ ManoloCuadra.html>. 31 mayo 2013.

Cuadra, Pablo Antonio. Aventura literaria del mestizaje y otros ensayos. San José, C.R.: Libro Libre, 1988.

Darío, Rubén. Poesías completas. Madrid: Aguilar, 1961.

Dennis, Philip A. "The Miskito-Sandinista Conflict in Nicaragua in the 1980s". Latin American Research Review 28/1 (1990): 214-34.

Duncan, Quince. Contra el silencio: Afrodescendientes y racismo en el Caribe Continental Hispánico. San José, C.R.: Editorial Universidad Estatal a Distancia, 2001.

Edison, Thomas Wayne. "La cultura afro-caribeña vista en la poesía: la tradición del Palo de mayo en el poema, 'Si yo fuera mayo' por Carlos Rigby Moses”. Revista Wani 49 (2007): 21-32.

Espinoza Moncada, Salvador. "David McField, esencia viva de nuestra multiculturalidad". El Nuevo Diario. 15 mayo 2012. <http://www.elnuevodiario.com.ni/ variedades/251303-david-mcfield-esencia-viva-de-nuestra-multiculturalidad $>$. 21 abril 2014. 
Estrada Colindres, Isabel. "Yesterday". Bluefields en la sangre: Poesía del Caribe Sur Nicaragüense. Eddy Alemán Porras y Franklin Brooks Vargas, eds. Managua: 400 Elefantes, 2011. 118-119.

FADCANIC. Fundación para la Autonomía y Desarrollo de la Costa Atlántica de Nicaragua. "Regiones Autónomas de Nicaragua". <http://www.fadcanic.org.ni/ ?q=es/node/18>. 25 mayo 2013 .

Falola, Toyin y Kevin D. Roberts, eds. The Atlantic World 1450-2000. Bloomington: Indiana UP, 2008.

Fenton, Annette. "Di first thing". <http://www.yorku.ca/cerlac/uraccan/URACCAN update_agosto2002.htm\#Poem>. 08 marzo 2006.

Frühling, Pierre, Miguel González y Hans Petter Buvollen. Etnicidad y nación: El desarrollo de la autonomía de la Costa Atlántica de Nicaragua (1987-2007). Guatemala: F\&G, 2007.

González, Miguel. “Los indígenas y los “étnicos': Inclusión restringida en el Régimen de Autonomía en Nicaragua". Política e identidad: Afrodescendientes en México y América Central. Odile Hoffman, coord. México: Consejo Nacional para la Cultura y las Artes, 2010. 93-128.

Gordon, Edmund T.Disparate Diasporas: Identity and Politics in an African-Nicaraguan Community. Austin: Institute of Latin American Studies, U Texas P, 1998.

Green, Brenda. “Identity”. Bluefields en la sangre: Poesía del Caribe Sur Nicaragüense. Eddy Alemán Porras y Franklin Brooks Vargas, eds. Managua: 400 Elefantes, 2011. 132.

"Soy costeña". Bluefields en la sangre: Poesía del Caribe Sur Nicaragüense. Eddy Alemán Porras y Franklin Brooks Vargas, eds. Managua: 400 Elefantes, 2011. 129.

Grigsby, William. “Costa Caribe: pluriétnica, multilingüe, ¿autonómica?”. Revista Envío 258 (2003). <http://www.envio.org.ni/articulo/1281>. 07 dic. 2013.

Jackson, Richard L. Black Writers and Latin America: Cross-Cultural Affinities. Washington, DC: Howard UP, 1998.

Lacayo, Ileana. "Autonomía". <http://www.escritorasnicaragua.org/poesianica06. html>. 26 julio 2005.

Martínez, Lovette. "It Is Autonomy". Bluefields en la sangre: Poesía del Caribe Sur Nicaragüense. Eddy Alemán Porras y Franklin Brooks Vargas, eds. Managua: 400 Elefantes, 2011. 108.

Martínez Reinosa, Milagros y Félix Valdés García. “¿De qué Caribe hablamos?” El Gran Caribe en el siglo XXI: Crisis y respuestas. Luis Suárez Salazar y Gloria Amézquita, eds. Buenos Aires: CLACSO, 2013. 21-34.

McField, David. "Dios es negro". Nicaragua: El más alto canto. Nueva antología de la poesía nicaragüense. Héctor Avellán, ed. Managua: Instituto Nicaragüense de Cultura, 2012. 84.

$111 \frac{\text { Revista Iberoamericana, Vol. LXXXII, Núms. 255-256, Abril-Septiembre 2016, } 421-455}{\text { ISSN 0034-9631 (Impreso) }}$ 
En la calle de enmedio. Managua: Editora Nicaragüense, 1968.

Las veinticuatro (poemas y canciones). Managua: Ediciones Libromundo, 1975. Poemas para el año del elefante. Managua: s/p, 1970.

Poemas populares. Managua: Editorial El Carmen, 1972.

Monterrey, Julio. "Un burilado crisol”. Bluefields en la sangre: Poesía del Caribe Sur Nicaragüense. Eddy Alemán Porras y Franklin Brooks Vargas, eds. Managua: 400 Elefantes, 2011. 198-199.

Narciso, Edna. “Autonomía”. Bluefields en la sangre: Poesía del Caribe Sur Nicaragüense. Eddy Alemán Porras y Franklin Brooks Vargas, eds. Managua: 400 Elefantes, 2011. 63.

Nicaragua: El más alto canto. Nueva antología de la poesía nicaragüense. Héctor Avellán, ed. Managua: Instituto Nicaragüense de Cultura, 2012.

Obando Sánchez, Víctor. Introducción. Bluefields en la sangre: Poesía del Caribe Sur Nicaragüense. Eddy Alemán Porras y Franklin Brooks Vargas, eds. Managua: 400 Elefantes, 2011. 3-7.

Ramírez, Marvin. “Campos azules”. Bluefields en la sangre: Poesía del Caribe Sur Nicaragüense. Eddy Alemán Porras y Franklin Brooks Vargas, eds. Managua: 400 Elefantes, 2011. 97-98.

Ramírez, Sergio. Tambor olvidado. San José: Aguilar, 2007.

Rigby, Carlos. "Los pirománticos tendrán que habérselas con nosotros". El siglo de la poesía en Nicaragua. Julio Valle-Castillo, ed. Tomo III. Neovanguardia. Grupos del 60, independientes y poetas del 70 al 80 (1960-1980). Managua: Fundación Uno, 2005. 521-525.

"Nicaraibe soy". Bluefields en la sangre: Poesía del Caribe Sur Nicaragüense. Eddy Alemán Porras y Franklin Brooks Vargas, eds. Managua: 400 Elefantes, 2011. 78-82.

"Todo clasial / nada racial". El siglo de la poesía en Nicaragua. Julio ValleCastillo, ed. Tomo III. Neovanguardia. Grupos del 60, independientes y poetas del 70 al 80 (1960-1980). Managua: Fundación Uno, 2005. 525-530.

Romero V[argas], Germán. "La presencia africana en el Pacífico y el centro de Nicaragua”. Wani 13 (1992): 20-34

Roof, María. "Más allá de la revolución: Poesía por mujeres nicaragüenses". Latin American Essays 20 (2007): 97-109.

Rossman Tejada, Yolanda. "Raíces". $<$ http://www.poetasdelmundo.com/detalle-poetas. php?id=6541>. 7 nov 2011.

Shade, Eunice. “Imágenes eróticas de Natalia Hernández”. Marca Acme 4 enero 2006. <http://www.marcaacme.com/ articulo-view.php?id=87>. 1 abril 2006.

Sirias Duarte, Silvio. "Nicaragua multiétnica: ¿Una farsa para los costeños?” Hecho Magazine 1/4 (2009): 54-59. <http://hechomagazine.com/wp-content/uploads/ 2009/11/04_web.pdf>. 7 nov 2010.

$111 \frac{\text { Revista Iberoamericana, Vol. LXXXII, Núms. 255-256, Abril-Septiembre 2016, } 421-455}{\text { ISSN 0034-9631 (Impreso) }}$ 
Smart. Ian. Central American Writers of West Indian Origin: A New Hispanic Literature. Washington DC: Three Continents, 1984.

Tinkam, Karl. "I Have A Dream". Bluefields en la sangre: Poesía del Caribe Sur Nicaragüense. Eddy Alemán Porras y Franklin Brooks Vargas, eds. Managua: 400 Elefantes, 2011. 215-216.

"Soy quien soy". Bluefields en la sangre: Poesía del Caribe Sur Nicaragüense. Eddy Alemán Porras y Franklin Brooks Vargas, eds. Managua: 400 Elefantes, 2011. 218-219.

Torres-Rivas, Edelberto. "Los avatares del Estado nacional en Nicaragua”. Prólogo. Etnicidadynación: el desarrollo de la autonomía de la Costa Atlántica de Nicaragua. Frühling, González y Buvollen. Guatemala: F\&G, 2007. xiii-xx

URACCAN, Universidad de las Regiones Autónomas de la Costa Caribe Nicaragüense. "Reseña histórica de la Universidad”. 21 nov. 2011. <http://uraccan.edu.ni/web/ library/ library.seam?libraryId=667\&print=false\&cid=2252145>. 1 mayo 2013.

Urtecho, Álvaro. Reseña de: Vilas, Carlos M. Del colonialismo a la autonomía: modernización capitalista y revolución social en la Costa Atlántica. Managua: Editorial Nueva Nicaragua, 1990. Revista Wani 10 (1991): 100-101.

Valle-Castillo, Julio. "Los cien años de Santos Cermeño y de Bluefields". El Nuevo Diario 6 oct. 2003. <http://archivo.elnuevodiario.com.ni/2003/octubre/06-octubre-2003/ cultural/ cultural7.info $>31$ mayo 2013.

Valle-Castillo, Julio, ed. El siglo de la poesía en Nicaragua. Tomo III. Neovanguardia. Grupos del 60, independientes y poetas del 70 al 80 (1960-1980). Managua: Fundación Uno, 2005.

Vilas, Carlos M. Del colonialismo a la autonomía: modernización capitalista y revolución social en la Costa Atlántica. Managua: Editorial Nueva Nicaragua, 1990.

Watson, Andira. "Diosa negra". En casa de Ana los árboles no tienen culpa. Managua: ANIDE, 2009.

"Las reacciones de la sociedad frente a una literatura de mujeres indígenas y afrodescendientes: Una reflexión desde la literatura de mujeres de la Costa Caribe Nicaragüense". Wani 56 (2007): 51-59.

"Reclamo de Negritud". 11 oct. 2011. <http://andirawatson.blogspot.com/>. 7 nov 2011.

"Rotundamente negra". Nicaragua: El más alto canto. Nueva antología de la poesía nicaragüense. Héctor Avellán, ed. Managua: Instituto Nicaragüense de Cultura, 2012. 224.

“Zimbabwe en la memoria". 14 sep. 2010. <http://andirawatson.blogspot.com/ 2010/09/zimbabwe-en-la-memoria.html>. 21 sept 2011.

Yllescas Salinas, Edwin. "Afro-caribeños en Managua". El Nuevo Diario. 27 junio 2000. <http://archivo.elnuevodiario.com.ni/2000/junio/27-junio-2000/opinion/ opinion2.html>. 7 nov. 2013.

$111 \frac{\text { Revista Iberoamericana, Vol. LXXXII, Núms. 255-256, Abril-Septiembre 2016, } 421-455}{\text { ISSN 0034-9631 (Impreso) }}$ 
